by silver staining. No other organisms were detected.

\section{Method}

After addition of an equal volume of sputolysin (Behring Diagnositics) and glass beads the sample was vortexed for one minute and the incubated at $37^{\circ} \mathrm{C}$ for three minutes. A total of $10 \mathrm{ml}$ of phosphate buffered saline (PBS) $\mathrm{pH}$ $7 \cdot 2$ was added and the mixture centrifuged at $2500 \mathrm{~g}$ for 20 minutes. The pellet was resuspended in $1 \mathrm{ml}$ PBS and cytospin preparations made on two polyl-lysine coated slides. A cytospin preparation of positive rat lavage material was used as a positive control. After fixation for 30 minutes in equal volumes $(50 \%)$ methanol and acetone, trypsin $(0 \cdot 25 \%)$ digestion for 10 minutes at $37^{\circ} \mathrm{C}$ followed. A standard wash procedure of three five minutes with PBS was carried out.

Mouse monoclonal antibody to $P$ carinii (Northumbria Biologicals Limited) was added to the test and positive control slides and PBS only, and incubated for $\mathbf{4 0}$ minutes. After repeat washing antimouse IgG (F'ab) conjugated to fluorescein isothiocyanate was added and a further incubation of 40 minutes followed. After a last wash procedure substituting PBS pH 8.4 for the final change, the slides were mounted and viewed under ultraviolet light.

The sample was considered positive when three typical cysts showing all over fluorescence were seen, further confirmed by methenane silver treatment of the control slide.

\section{Discussion}

In HIV infection, the diagnosis of $P$ carinii pneumonia has important implications, not only for the treatment of the acute illness, but also for longer term prognosis. In New York 13 out of 15 children less than 6 months old with $P$ carinii pneumonia died during the acute episode, and all were dead by one year ( $J$ Chow, $K$
Shah, $\mathrm{K} \mathrm{Li}$, et al; abstract presented at $\mathrm{V}$ International Conference on AIDS, Montreal, June 1989. Because of the risks involved in, and the technical expertise required for, paediatric bronchoscopy treatment is usually empirical. If the child dies, postmortem examination may give the answers, but if the child responds to high dose cotrimoxazole, the differential diagnosis between a bacterial pneumonia and $P$ carinii pneumonia remains unresolved. This then creates difficulties in classification and staging of the child's disease, and in making therapeutic decisions, such as whether to commence zidovudine or prophylaxis for $P$ carinii pneumonia.

Identification of $P$ carinii pneumonia from upper respiratory tract secretions may only be possible in cases of overwhelming infection, and failure to detect it by this method does not exclude the diagnosis. It is in the most severe cases, however, that the patient is least able to tolerate more invasive procedures. Because our technique is rapid, other methods can still be used thereafter without undue delay. We believe therefore that it should be used as the first line investigation of suspected $P$ carinii pneumonia.

RAH is supported by the Medical Research Council. We thank the staff in wards 7A and 15 at the City Hospital for their help and support.

1 Barter S. The radiology of AIDS. Br $\mathcal{F}$ Hosp Med 1987;38: $214-8$.

2 Wolff LJ, Bartlett MS, Baehner RL, et al. The causes of interstitial pneumonia in immunocompromised children: an aggressive systematic approach to diagnosis. Pediatrics an aggressive

3 De Blic J, McKelvie P, Le Bourgeois $M$, et al. Value of bronchoalveolar lavage in the management of severe acute bronchoalveolar lavage in the management of severe acute pneumonia and interstitial pneumonitis in

4 Zaman MK, Wooten OJ, Suprahmanya B, et al. Rapid noninvasive diagnosis of Pneumocystis carinii from induced liquefied sputum. Ann Intern Med 1988;109:7-10

5 Williford Pifer LL, Woods DR, Edwards CC, et al. Pneumocystis carinii serologic studies in pediatric acquired immunodefiency syndomre. Am $\mathcal{F}$ Dis Child 1988;142:36-
The Royal Liverpool Children's Hospital Alder Hey

A Mark Dalzell Hendrik $K$ F van Saene David P Heaf

Correspondence to: Dr A Mark Dalzell, Hospital Herston Road,

Brisbane,

Queensland, 4029, Australia.

Accepted 5 July 1990

(Anch Dis Child 1990;65:1365-7).

\title{
Cystic fibrosis, Pseudomonas aeruginosa, and selective decontamination
}

\author{
A Mark Dalzell, Hendrik K F van Saene, David P Heaf
}

\author{
Abstract \\ We used an oral topical antibiotic preparation \\ to try and prevent oropharyngeal carriage of \\ Pseudomonas aeruginosa in patients with \\ cystic fibrosis. Ten of 15 patients treated with \\ a two week course of intravenous ceftazidime \\ together with a 90 day course of an antibiotic \\ containing gel continued to carry $P$ aerugi- \\ nosa in the oropharynx.
}

The technique of selective decontamination of the digestive system uses oral antibiotic combinations to prevent the overgrowth of certain groups of organism (typically Gram negative aerobes), and allows the more usual flora to maintain colonisation resistance. ${ }^{1}$ It has application particularly in the immunocompromised patient undergoing cytotoxic chemotherapy and in long term ventilated patients, ${ }^{2}$ where Gram 
negative aerobes normally confined to the large bowel may colonise first the oropharynx and then the lower respiratory tract.

The principle of selective decontamination has been previously adopted in cystic fibrosis patients carrying Pseudomonas aeruginosa when using antipseudomonal agents delivered by aerosol. ${ }^{3}$ Although this treatment has been successful in reducing the number of pseudomonas isolates, and in reducing the frequency of lower respiratory tract exacerbations, it has proved impossible to eradicate $P$ aeruginosa. This pilot study was conducted in order to find out whether an oral topical antibiotic preparation could prevent oropharyngeal carriage.

\section{Subjects and methods}

The study group comprised cystic fibrosis patients from whom $P$ aeruginosa was isolated for the first time in consecutive oropharyngeal samples during a period of two weeks. All patients took flucloxacillin as prophylaxis against staphylococcal colonisation of the respiratory tract.

Patients were admitted to hospital regardless of clinical condition, and treated initially with intravenous ceftazidime $(150 \mathrm{mg} / \mathrm{kg} / \mathrm{day})$ for 14 days. In addition a selective decontamination gel composed of a $2 \%$ mixture of polymyxin $E$, tobramycin, and amphotericin B in a $3.5 \%$ carboxymethyl cellulose base was applied topically to the buccal mucosa and gingiva four times a day after meals. On completion of the initial inpatient stay a further 76 days of oral gel application was completed at home.

Respiratory tract infections (both upper and lower) during the period of the study were treated on merit. Upper respiratory coryzal illness was treated with an additional oral antibiotic either amoxycillin, erythromycin, or trimethoprim, and lower respiratory infections unresponsive to the above antibiotics were treated with oral ciprofloxacin, nebulised aminoglycoside, or intravenous ceftazidime.

\section{BACTERIOLOGICAL MONITORING}

Weekly throat and rectal swabs, together with lower airway samples, were cultured prospectively throughout and subsequent to the treatment period. All samples were cultured both qualitatively and quantitatively.

\section{Quantitative culture}

An aliquot of $1 \mathrm{ml}$ or $1 \mathrm{~g}$ of specimen was suspended in a sterile culture tube containing 9 $\mathrm{ml}$ of brain heart infusion (BHI broth, No 49, Lab $\mathbf{M}$ ). All specimens were serially diluted (1:10 steps), subcultured onto solid media using the four quadrant method, and the tip of the swab was broken off into broth. The concentrations of micro-organisms were estimated on a scale of $1+$ to $5+$. If only broth was positive, the growth density was recorded as $1+$ (according to $\leqslant 10^{1}$ colony forming units (cfu)/ml or $\mathrm{g}$ ); macroscopic growth in the first quadrant scored $2+$ (according to $\leqslant 10^{3} \mathrm{cfu} / \mathrm{ml}$ or $\mathrm{g}$ ) etc.

\section{Qualitative culture}

Morphologically distinct colonies were isolated in pure culture and identified by standard procedures (analytical profile index $20 \mathrm{E}$, coagulase, etc). Antibiotic sensitivities were determined using a controlled disc diffusion method for each of the different isolates. The antibacterial agents used for flora suppression (polymyxin E, tobramycin) and for systemic treatment (ceftazidime) were tested.

\section{Definitions}

Oropharyngeal carriage was defined as the presence of identical pseudomonas species in any concentration in at least two consecutive throat swabs over a period of two weeks.

Infection of the upper respiratory tract was a clinical diagnosis based on rhinorrhoea and cough thought to be viral in origin in most cases. Infection of the lower airways was a microbiologically proved clinical diagnosis with the sample yielding $100000 \mathrm{cfu} / \mathrm{ml}$ or more.

The effectiveness of the topical antimicrobial gel during this study was judged by the eradication and/or prevention of $P$ aeruginosa carriage in the oropharynx. In addition, Fisher's exact test and Student's $t$ test were used to compare respiratory exacerbations, the use of additional antibiotics, and weight gain during the study period and for the subsequent 90 days.

\section{Results}

Fifteen children (nine boys and six girls) with cystic fibrosis, mean age 7.5 years ( 18 months15.6 years) were assessed. Three patients failed

Table 1 Clinical details of cystic fibrosis patients

\begin{tabular}{|c|c|c|c|c|c|}
\hline $\begin{array}{l}\text { Patient } \\
\text { No }\end{array}$ & $\begin{array}{l}\text { Age at } \\
\text { diagnosis } \\
\text { (months) }\end{array}$ & $\begin{array}{l}\text { Shwachman } \\
\text { score when } \\
\text { colonised }\end{array}$ & $\begin{array}{l}\text { Age at } \\
\text { which } P \text { aeruginosa } \\
\text { colonised } \\
\text { (months) }\end{array}$ & $\begin{array}{l}\text { Continued } P \text { aeruginosa } \\
\text { isolation during } \\
\text { selective decontamination } \\
\text { period }\end{array}$ & $\begin{array}{l}P \text { aeruginosa isolation } \\
\text { three months } \\
\text { after selective } \\
\text { decontamination period }\end{array}$ \\
\hline $\begin{array}{r}1 \\
2 \\
3 \\
4 \\
5 \\
6 \\
7 \\
8 \\
9 \\
10 \\
11 \\
12\end{array}$ & $\begin{array}{r}2 \\
17 \\
2 \\
30 \\
6 \\
2 \\
2 \\
27 \\
3 \\
18 \\
24 \\
48\end{array}$ & $\begin{array}{l}65 \\
75 \\
60 \\
60 \\
75 \\
90 \\
90 \\
95 \\
85 \\
60 \\
55 \\
85\end{array}$ & $\begin{array}{r}89 \\
69 \\
178 \\
153 \\
10 \\
111 \\
52 \\
137 \\
24 \\
23 \\
92 \\
64\end{array}$ & $\begin{array}{l}\text { Yes } \\
\text { Yes } \\
\text { Yes } \\
\text { Yes } \\
\text { Yes } \\
\text { Yes } \\
\text { Yes } \\
\text { Yes } \\
\text { No } \\
\text { Yes } \\
\text { Yes } \\
\text { No }\end{array}$ & $\begin{array}{l}\text { Yes } \\
\text { Yes } \\
\text { Yes } \\
\text { Yes } \\
\text { Yes } \\
\text { Yes } \\
\text { Yes } \\
\text { Yes } \\
\text { No } \\
\text { Yes } \\
\text { Yes } \\
\text { No }\end{array}$ \\
\hline
\end{tabular}


Table 2 Group data during and after the period of selective decontamination. Values are expressed as mean (range) for the group of 12 patients

\begin{tabular}{lll}
\hline & $\begin{array}{l}\text { Selective } \\
\text { decontamination } \\
\text { period (90 days) }\end{array}$ & $\begin{array}{l}90 \text { Days after } \\
\text { decontamination } \\
\text { period }\end{array}$ \\
\hline $\begin{array}{l}\text { No of episodes upper } \\
\text { respiratory tract } \\
\text { infections }\end{array}$ & $0.8(0-3)$ & $1.1(0-3)$ \\
$\begin{array}{l}\text { No of episodes lower } \\
\text { respiratory tract } \\
\text { infections }\end{array}$ & $1.9(1-4)$ & $1.8(1-3)$ \\
$\begin{array}{l}\text { Weight gain (kg) } \\
\text { No of courses } \\
\text { additional antibiotics }\end{array}$ & $2.9(-0.6-5 \cdot 75)$ & $1.4(0.15-3.3)$ \\
\hline
\end{tabular}

There was no significant difference for any of the above variables between the selective decontamination period and the subsequent 90 days.

to complete the study: one did not fulfill the entry criteria and two patients did not like applying the oral gel. Clinical details of the 12 patients who completed the study are shown in table 1.

Ten patients $(83 \%)$ continued to yield $P$ aeruginosa from the throat and sputum during the treatment period and from the oropharynx during the three months after completion of the study $(p=0 \cdot 3) . P$ aeruginosa was intermittently cultured from rectal swabs taken from three patients during the study period.

Table 2 shows clinical data for the selective decontamination period and the subsequent 90 days. There was no detectable benefit to the patient during the selective decontamination period in terms of weight gain or reduced frequency of respiratory exacerbations.

\section{Discussion}

Together with Staphylococcus aureus and Haemophilus influenzae, $P$ aeruginosa is the commonest isolate from the oropharynx of patients with cystic fibrosis. Sporadic isolates of $P$ aeruginosa are not unusual in patients with cystic fibrosis, but once oropharyngeal carriage has occurred, eradication is rare. The application of an oral selective decontamination gel was of no benefit to 10 out of 12 patients in preventing carriage of $\boldsymbol{P}$ aeruginosa within the oropharynx. The organism ultimately colonises most patients and has at least two strategies to facilitate survival. Once established in the respiratory tract, mucoid variants are commonly found. The 'slime' probably protects colonies from host defences, and intramural proteins have been identified in $P$ aeruginosa, which may protect against antibiotic attack. Pseudomonas is not an oropharyngeal commensal, nor is it cultured from stool unless a large inoculum $\left(10^{6}\right)$ is ingested orally. Even then, in normal individuals colonisation of the bowel does not occur. ${ }^{4}$ Three patients were identified as having pseudomonal colonisation of the bowel because of repeated isolates from rectal swabs during attempted oral selective decontamination.

The failure of a selective decontamination approach in cystic fibrosis may be due to a number of factors. Lindemann $e t$ al found that the orophyarynx is a reservoir for the organism which may colonise by virtue of its preferred attachment to altered epithelial surfaces in the oropharynx of cystic fibrosis patients. ${ }^{5}$ In contrast to the success achieved in ventilated patients where an antibiotic containing paste has been effective, ${ }^{2}$ it was necessary to use an antibiotic containing gel because of the unpalatability of paste. The mucosal contact time of the gel compared with paste may have reduced antibiotic effectiveness. The reasons why patients with cystic fibrosis are colonised by $P$ aeruginosa are still unclear, and the difficulties encountered in trying to prevent carriage of the organism remain.

AMD is in receipt of a cystic fibrosis research fellowship.

1 van Saene HKF, Stoutenbeek CP. Leading article. Selective decontamination. 7 Antimicrob Chemother 1987;20:462-5.

Stoutenbeek CP, van Saene HKF, Miranda DR, Zandstra DF, Langrehr D. Nosocomial Gram-negative pneumonia in critically ill patients. Intensive Care Med 1986;12:419-23. in critically ill patients. Intensive Care Med 1986;12:419-23. odson ME, Penketh ARL, Batten JC. Aerosol carbenicillin and gentamicin treatment of Pseudomonas aeruginosa infection

4 Buck AC, Cooke EM. The fate of ingested Pseudomonas aeruginosa in normal persons. $\mathcal{J}$ Med Microbiol 1969;2: aerugin $521-5$

5 Lindemann RA, Newman MG, Kaufman AK, Le TV. Oral colonization and susceptibility testing of Pseudomonas aeruginosa oral isolates from cystic fibrosis patients. $\mathcal{F}$ Dent Res 1985;64:54-7.

\title{
Nocturnal faecal soiling and anal masturbation
}

\author{
A F Clark, P J Tayler, S R Bhate
}

Young People's Unit, Newcastle General Hospital,

Westgate Road,

Newcastle upon Tyne

NE4 6BE

A F Clark

P J Tayler

S R Bhate

Correspondence to:

Dr Clark.

Accepted 1 July 1990

(Anch Dis Child 1990;65:1367-8).

\section{Abstract}

Two cases of late onset faecal soiling as a result of anal masturbation in children who were neither mentally handicapped nor psychotic were studied. The role of soiling in aiding the young person and his family to avoid separating and maturing is highlighted. We suggest that the association of anal masturbation and resistant nocturnal soiling may be unrecognised.

Faecal soiling is defined as disordered bowel function and control occurring in children over a certain age in the absence of any physical abnormality or disease. ${ }^{1}$ The prognosis is good, with remission occurring before adulthood. This has made it difficult to assess the effectiveness of intervention. ${ }^{2}$ A steady decline in symptoms was recorded from the age of 6 years in boys and 8 years in girls in the follow up of 186 children attending child psychiatric clinics. ${ }^{3}$ All were clean by the age of 16 years, apart from two relapses, one at 17 and one at 19 years. It has been suggested that encopresis in adulthood is a feature of either psychotic disorder or severe mental handicap, and there have been reports of 